Portland State University

PDXScholar

\title{
Spatiotemporal Variability of Twenty-First-Century Changes in Site-Specific Snowfall Frequency Over the Northwest United States
}

Arielle J. Catalano

Portland State University, a.j.catalano@pdx.edu

Paul C. Loikith

Portland State University, ploikith@pdx.edu

C. M. Aragon

Oregon State University

Follow this and additional works at: https://pdxscholar.library.pdx.edu/geog_fac

Part of the Physical and Environmental Geography Commons

Let us know how access to this document benefits you.

\section{Citation Details}

Catalano, A. J., Loikith, P. C., \& Aragon, C. M. (2019). Spatiotemporal variability of twenty-first-century changes in site-specific snowfall frequency over the Northwest United States. Geophysical Research Letters, 46, 10,122-10,131. https://doi.org/10.1029/2019GL084401

This Article is brought to you for free and open access. It has been accepted for inclusion in Geography Faculty Publications and Presentations by an authorized administrator of PDXScholar. Please contact us if we can make this document more accessible: pdxscholar@pdx.edu. 


\section{Geophysical Research Letters}

\author{
RESEARCH LETTER \\ 10.1029/2019GL084401 \\ Key Points: \\ - Days receiving snow versus rain are \\ projected to decline at specified sites \\ in the Northwest, and declines are \\ nonlinear after midcentury \\ - Snowfall frequency declines are \\ largest at low-elevation sites, leading \\ to shortened time horizons for \\ critical declines over this century \\ - The atmospheric approach used \\ demonstrates utility in delineating \\ site-to-site snowfall frequency \\ variability using coarse-resolution \\ data
}

Supporting Information:

- Supporting Information S1

- Table S1

Correspondence to:

A. J. Catalano,

a.j.catalano@pdx.edu

Citation:

Catalano, A. J., Loikith, P. C., \& Aragon, C. M. (2019). Spatiotemporal variability of twenty-first-century changes in site-specific snowfall frequency over the Northwest United States. Geophysical Research Letters, 46, 10,122-10,131. https://doi.org/10.1029/ 2019GL084401

Received 2 JUL 2019

Accepted 7 AUG 2019

Accepted article online 16 AUG 2019

Published online 26 AUG 2019

(c)2019. American Geophysical Union. All Rights Reserved.

\section{Spatiotemporal Variability of Twenty-First-Century Changes in Site-Specific Snowfall Frequency Over the Northwest United States}

\author{
A. J. Catalano ${ }^{1}$ (D, P. C. Loikith ${ }^{1}$ (D), and C. M. Aragon ${ }^{2}$ \\ ${ }^{1}$ Department of Geography, Portland State University, Portland, OR, USA, ${ }^{2}$ Water Resources Science, Oregon State \\ University, Corvallis, OR, USA
}

Abstract In the Northwest United States, warming temperatures threaten mountain snowpacks. Reliable projections of snowfall changes are therefore critical to anticipate the timeline of change. However, producing such projections is challenging, as most state-of-the-art climate models are limited in sufficiently resolving influential topography. Here we leverage atmospheric freezing level to estimate precipitation phase and project twenty-first-century snowfall frequency change at Snowpack Telemetry Network stations across the Northwest. Under "moderate" and "business-as-usual" emission pathways in Coupled Model Intercomparison Project phase 5 models, snowfall frequency is projected to decline at all stations. Business-as-usual declines accelerate after midcentury at most locations, whereas moderate declines decelerate. A "critical year" analysis identifies when decadal-mean snowfall frequency is projected to fall below $50 \%, 25 \%$, and $10 \%$ of cold-season wet days. Results highlight regions particularly vulnerable to relatively near-term change, such as the Cascade Range. Considerable station-to-station spatial variability emphasizes the value of this site-specific approach.

Plain Language Summary In the Northwest United States, warming temperatures threaten mountain snow resources, which supply freshwater in watersheds throughout the region. Reliable estimates of future snowfall changes are therefore crucial to determine the timeline over which these changes may occur. However, the tools generally used to estimate future snowfall, climate models, have difficulty calculating local changes across mountainous landscapes. Towards addressing this challenge, we use the height where temperature equals freezing to estimate snowfall versus rainfall occurrence over this century, from which snowfall frequency changes in climate models are calculated at point locations across the Northwest. Under "business-as-usual" and "moderate" greenhouse gas emissions, average snowfall frequency is estimated to decline at all sites by 2100 . The rate of decline under business-as-usual emissions increases in the latter half of this century at most locations, whereas moderate rates decrease. A "critical year" identifies when the number of snow days averaged over 10 years falls below 50\%, 25\%, and $10 \%$ of all days receiving rain or snow. Results highlight regions that may experience critical snowfall frequency declines sooner, such as the Cascade Range. Differences among locations are considerable, emphasizing the value of this site-specific approach.

\section{Introduction}

Threats to the reliability of freshwater resources are becoming of critical concern due to ongoing climate warming. This is particularly acute in the Northwest United States (NUS) where water availability in climatologically dry summers is often contingent upon groundwater recharge by melt from mountain snowpacks. Historically, warming surface temperatures have been the primary driver of earlier springtime snowmelt (Stewart et al., 2005) and substantial declines in snow cover across the NUS (Mote et al., 2005; Mote et al., 2018). These changes in freshwater storage affect those relying on this source including irrigated agriculture, hydropower production, and terrestrial and aquatic ecosystems.

Although projections of changes in NUS precipitation over the twenty-first century exhibit uncertainty (USGCRP, 2017), rising temperatures will likely lead to an increase in the proportion of precipitation falling as rain instead of snow (Ashfaq et al., 2013; Feng \& Hu, 2007; Knowles et al., 2006). However, the rate of change in this proportion is unlikely to be homogenous across the NUS, emphasizing the need for local-scale projections. Knox et al. (2017) partitioned precipitation phase at the surface using spatially uniform 
temperature thresholds, but observed temperatures during snowfall exhibit considerable variability in mountainous areas (Jennings et al., 2018). Many studies use general circulation models (GCMs) to quantify projected snowfall at the surface (Danco et al., 2016; Kapnick \& Delworth, 2013), but coarse-resolution GCMs cannot adequately resolve complex topography that results in elevation-dependent snowpack climatology. This leads to uncertainty in simulated snowfall estimates over mountainous regions like the NUS. Statistical downscaling can be applied to calculate finer-scale snowfall changes (Lute et al., 2015), but includes uncertainty due to assumptions such as stationarity in relationships between predictors and predictands in a warming climate (Schmith, 2008). Toward addressing these challenges, this work provides an atmospheric approach to assessing the influence of climate change on site-specific snowfall frequency over the mountainous NUS.

Snowfall frequency can be characterized through changes in freezing level (FL), the altitude above sea level of the $0{ }^{\circ} \mathrm{C}$ isotherm, which indicates where falling snow begins the melting process. In the NUS, many snow-fed watersheds are located at elevations close to the climatological FL, and are therefore considered at risk to becoming rain-dominated even under modest warming (Abatzoglou, 2011; Nolin \& Daly, 2006). Prior work linked positive trends in historical FL to rapid deglaciation over the tropics (Bradley et al., 2009) and in High Asia (Wang et al., 2014), as well as earlier snowmelt in China (Zhang \& Guo, 2011). Future changes in FL will have substantial effects on snowfall and snowpacks (Schauwecker et al., 2017), but existing work in this area is limited in scope over the NUS. Therefore, this research leverages estimates of projected FLs to examine the spatiotemporal variability in snowfall frequency over the twentyfirst century.

\section{Data}

Observations of snow water equivalent (SWE) and precipitation are from Snowpack Telemetry Network (SNOTEL) measurements. SNOTEL stations are often used to monitor water availability in mountainous regions (Serreze et al., 1999), providing an observational baseline for defining snowfall. Only SNOTEL stations with $<15 \%$ of data missing for water years across the historical period 1981-2005 are used (Blandford et al., 2008), which retains a sample of 157 stations (Tables S1-S3). To compute historical FL, temperature and geopotential height data are obtained from the latest European Centre for MediumRange Weather Forecasts reanalysis product, ERA5 (developed through the Copernicus Climate Change Service, 2017). As data assimilation schemes differ among reanalysis products, results from ERA5 were compared with results from the North American Regional Reanalysis (Mesinger et al., 2006). North American Regional Reanalysis is found to be in good agreement with ERA5, so only ERA5 is discussed further.

Climate model data are from the GCMs contributing to phase 5 of the Coupled Model Intercomparison Project (CMIP5; Taylor et al., 2012). Historical simulations are utilized for comparisons with SNOTEL and ERA5 across an overlapping period (1981-2005). To examine projections of anthropogenic warming, we employ simulations using two Representative Concentration Pathways (RCPs), "business as usual" (RCP8.5) and "moderate" (RCP4.5), over water years 2007-2099. RCP8.5 is chosen as global carbon emissions are currently following the trajectory of this scenario (USGCRP, 2017). RCP4.5 provides a mitigation scenario in which emissions decline after 2040 (Thomson et al., 2011). Only GCMs providing complete output for historical, RCP4.5, and RCP8.5 simulations are selected, yielding 20 models (Table S4).

\section{Methods}

Analyses are conducted over Oregon, Washington, and Idaho, representing the Northwest region of the United States National Climate Assessment, over cold-season months spanning the current snowpack accumulation season (November-April). Gridded data sets are regridded to a $2^{\circ} \times 2^{\circ}$ latitude/longitude grid, and only data at grid cells spatially coincident with SNOTEL stations are utilized.

\subsection{Freezing Level}

Daily mean FL is computed by linearly interpolating to the height above mean sea level at which air temperature first equals $0{ }^{\circ} \mathrm{C}$ in the column (Bradley et al., 2009; Schauwecker et al., 2017) based on available data at five pressure levels common across all data sets $(1000,850,700,500$, and $250 \mathrm{hPa})$. As some data sets provide daily data at levels that are below the land surface while others do not, low-level data are removed if 
geopotential height is below the elevation of SNOTEL stations (Tables S1-S3) to ensure a uniform process of computing FL across all data sets. Then, temperature is extrapolated downward using a constant lapse rate. Previous studies have applied moist adiabatic lapse rates including $-6.5^{\circ} \mathrm{C} \mathrm{km}^{-1}$ (Maurer et al., 2002; Schauwecker et al., 2017) and $-6.1^{\circ} \mathrm{C} \mathrm{km}^{-1}$ (Hamlet et al., 2005; Kapnick \& Hall, 2012) to extrapolate temperature data. Minder et al. (2010) determined that the simulated lapse rate across the Cascade Range is approximately $-5.7^{\circ} \mathrm{C} \mathrm{km}^{-1}$ under "stormy conditions" ( $>2 \mathrm{~mm} / 12 \mathrm{hr}$ ), which closely corresponds to the average cold-season lapse rate derived from National Weather Service Cooperative stations in the same study. Therefore, we perform extrapolations using $-5.7,-6.1$, and $-6.5{ }^{\circ} \mathrm{C} \mathrm{km}^{-1}$ to assess the sensitivity of FL to lapse rate. Figures in the main manuscript use a $-6.1^{\circ} \mathrm{C} \mathrm{km}^{-1}$ lapse rate, and corresponding results using the other two lapse rates are provided in the supporting information. We note that using the same lapse rate across the domain provides a useful approximation but comes with the caveat that lapse rates may not be spatially uniform (Blandford et al., 2008; Dobrowski et al., 2009; Pepin \& Losleben, 2002).

\subsection{Snow Level}

To more precisely identify the effective altitude at which snow transitions to rain, we adjust the FL to compute a "snow level" (SL). The transition from frozen to liquid precipitation can occur over a considerable vertical distance as a result of adiabatic and diabatic processes while an air mass intersects a mountain range. Lundquist et al. (2008) noted that the California-Nevada River Forecast Center generally applied a correction ranging 300-460 m below FL. To our knowledge, SL displacement over the NUS has not been previously evaluated. Therefore, we assume a constant displacement height of $300 \mathrm{~m}$ below computed FL to approximate SL over mountainous terrain. As SL is lower than FL, this approximation provides a more conservative timeline for projected snowfall frequency declines. We note that assumptions made in SL computation preclude consideration of subdaily temperature changes, which could result in snowfall where daily mean SL is above the surface as well as mixed-phase precipitation.

\subsection{Snowfall Frequency}

Snowfall frequency is computed at the point locations of SNOTEL stations in all data sets. Over the historical period, the two methods used to define days with snow occurring at the surface (hereafter, "snow days") are as follows. First, an in situ-based definition of observed snow days at each SNOTEL station is applied to days recording at least $7 \mathrm{~mm}$ of accumulated liquid equivalent precipitation (hereafter, "wet days") with a concurrent increase in SWE $\geq 7 \mathrm{~mm}$. A 7-mm threshold is chosen as it avoids a known "drizzle phenomenon" in CMIP5 models (Liu et al., 2014), and a concurrent SWE increase generally indicates that precipitation is snow directly accumulating into the snowpack. Second, a SL-based definition of snow days is computed using ERA5 and CMIP5 height and temperature data. If the height of the SL lies below the station elevation on a wet day, it is designated as a snow day. Historical snowfall frequency is then defined as the percentage of snow days over the record of wet days (1981-2005). Observation-based wet days use SNOTEL precipitation measurements, whereas CMIP5 wet days are based on model precipitation in grid cells spatially coincident with stations. Projected snowfall frequency is measured relative to the ERA5 historical snowfall frequency through changes in SL distributions. For each CMIP5 model, the projected change in SL distributions relative to its own historical simulation is applied to the ERA5 SL distribution at percentiles 1-100 to obtain future SL distributions at individual stations. This ensures that projected changes do not rely on the ability of CMIP5 models to precisely capture historical snowfall frequency at each station since models exhibit biases (Rupp et al., 2013). Furthermore, projected levels are computed at individual percentiles as changes in SLs may be asymmetrical across the distribution. From future SL distributions, snowfall frequency is obtained by linearly interpolating to the percentile of the SL equal to station elevation, representing the percentage of days with SL at or below station elevation (i.e., snow days) over all wet days. Projected snowfall frequencies are analyzed over two future periods, midcentury (2028-2052) and end of century (2075-2099), which are equally distributed from the historical period and segments of equivalent length.

\subsection{Critical Years}

The onset of critical changes in the low-altitude tail of the SL distribution is also investigated. Adjusted percentile distributions (see section 3.3) are computed for each cold season in the RCP simulations (2007-2099), and a 10-year running mean is then applied to smooth interannual variability in cold-season SLs. The first year of the decade (bounded by the 10-year running mean) during which a specified percentile of SLs 

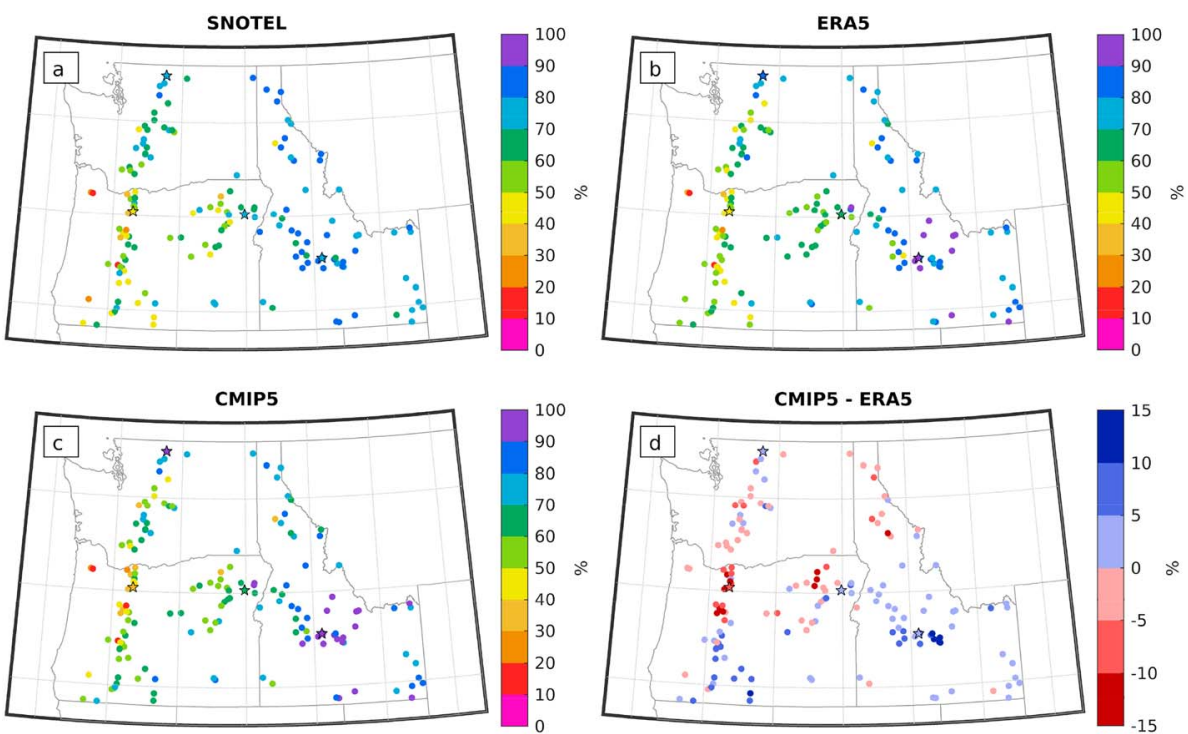

Figure 1. Snowfall frequency over the historical period (1981-2005) computed using (a) SNOTEL wet days concurrent with increasing SWE ( $\geq 7 \mathrm{~mm}$ ) and (b) ERA5 SLs and (c) CMIP5 multimodel mean SLs relative to station elevation. (d) Difference between multimodel mean and ERA5 snowfall frequencies. Stars indicate select stations analyzed in Figure 3.

rises above station elevation is defined as the "critical year." For example, a critical year of 2039 at the 25th percentile threshold means that 2039-2048 is the first 10-year period when $25 \%$ or less of wet days are snow days, as projected.

\section{Results}

Figure 1 displays the snowfall frequency climatology at each SNOTEL station, computed based on the in situ snow day definition using SNOTEL (Figure 1a), SLs from ERA5 (Figure 1b), and SLs from the CMIP5 historical simulation (Figure 1c). All three data sets capture the same principal climatological features of snowfall frequency including considerable spatial variability across the NUS, with stations experiencing less than $50 \%$ of wet days as snow days along the Oregon Cascades. SNOTEL and ERA5 snowfall frequencies generally agree, indicating the SL approach is robust, with a mean absolute error of the difference between frequencies across the NUS of 6.9\%. Differences could stem from a combination of factors including approximations in lapse rate and SL displacement height, SWE increasing from rainfall freezing into the snowpack (Lundquist et al., 2008), and errors in in situ SWE measurements (e.g., undercatch (Caldwell, 2010) and ice bridging (Smith et al., 2017)) and reanalysis data. Using ERA5 as reference, the SL approach for the CMIP5 multimodel mean identifies 17 of the 23 stations at which historical snowfall frequency is below $50 \%$ (Figures $1 \mathrm{~b}$ and 1c). The average difference between multimodel mean and ERA5 frequencies is only $0.2 \%$, but there are areas of positive and negative biases across the NUS, including substantial overestimation at stations in central Idaho, and the greatest underestimation over the northern Oregon Cascades (Figure 1d). However, standard deviations across CMIP5 models are within 10\% at over three quarters of stations (Figure S1), and a sensitivity analysis of snowfall frequency to lapse rate used for extrapolation also reveals minor differences in frequencies, at most $10 \%$ between the steepest $\left(-6.5^{\circ} \mathrm{C} \mathrm{km}^{-1}\right)$ and shallowest $\left(-5.7^{\circ} \mathrm{C} \mathrm{km}^{-1}\right)$ lapse rates (Figure S2).

Under both RCPs, all stations experience a decline in mean snowfall frequency over the twenty-first century, which varies roughly linearly with elevation (Figure S3). Under RCP8.5, 70 of the 157 stations record less than $50 \%$ of wet days as snow days during an average cold season by midcentury (Figure 2a), which is 3 times the historical number as defined using ERA5 (Figure 1b). Standard deviations across CMIP5 models extend to $18 \%$ (Figure S4), but regional differences in midcentury snowfall frequency are largely consistent with station-based percent changes in annual cumulative SWE estimated by Lute et al. (2015) and empirically derived snowfall frequency declines in Klos et al. (2014). By the end of the century, 126 stations experience less than $50 \%$ snowfall frequency, and over two thirds of stations across Oregon and Washington receive 
RCP8.5
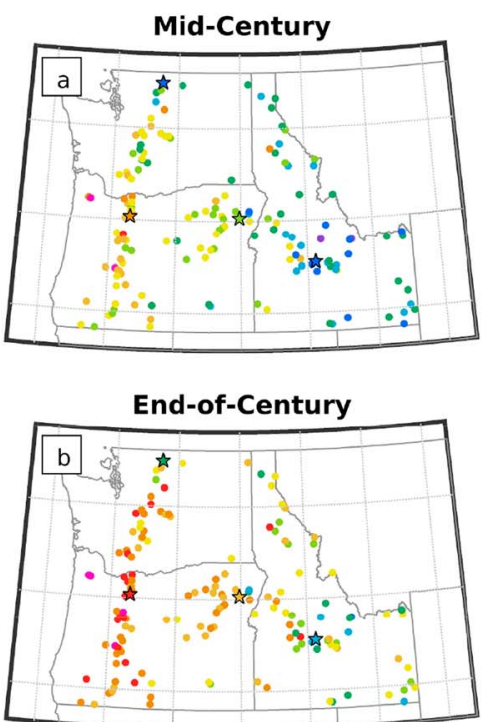

Mid-Century - Historical

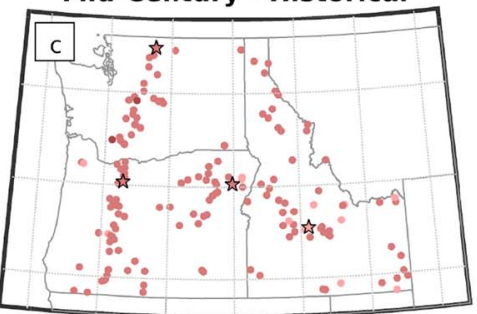

End-of-Century - Mid-Century

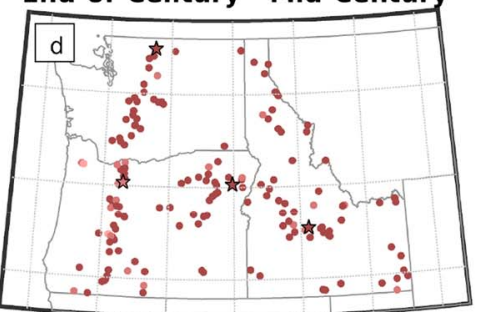

RCP4.5

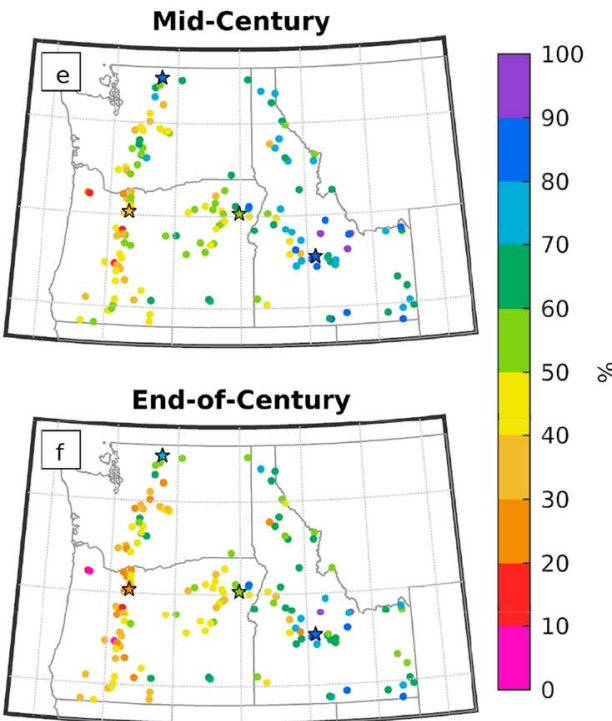

Mid-Century - Historical

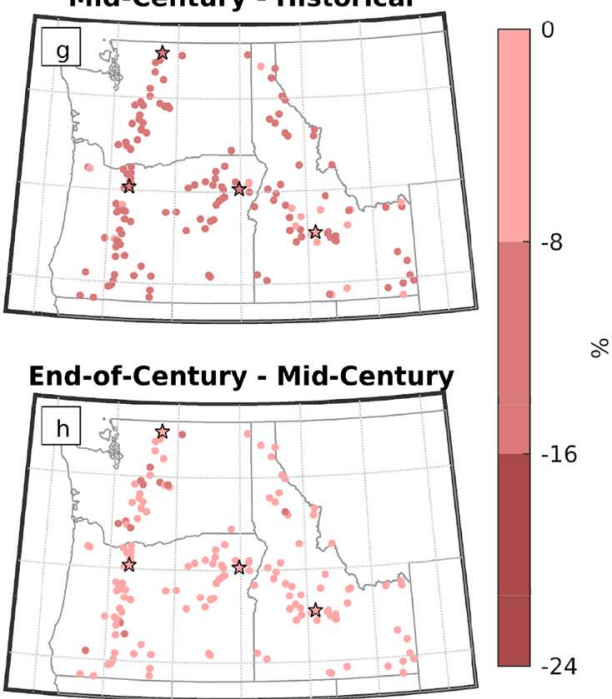

Figure 2. CMIP5 multimodel mean (left) RCP8.5 and (right) RCP4.5 projections of snowfall frequency (\% of wet days) at (a and e) midcentury (2028-2052) and (b and f) end of century (2075-2099). Difference between (c and g) midcentury and ERA5 historical snowfall frequencies and ( $\mathrm{d}$ and $\mathrm{h}$ ) end-of-century and midcentury frequencies. Stars indicate select stations analyzed in Figure 3.

snowfall for less than one third of average cold-season wet days (Figure 2b). However, the decline in mean snowfall frequency is not homogeneous across the NUS, nor is it uniform over the twenty-first century. All stations experience declines, but the rate of decline accelerates at $99.4 \%$ of SNOTEL stations between midcentury and end of century. Maximum declines in snowfall frequency by midcentury are $-16.2 \%$ (Figure 2c), whereas maximum declines during the second half of the century are $-23.4 \%$ (Figure $2 \mathrm{~d}$ ), signifying nonlinearity in the trend. RCP4.5 midcentury projections are similar to RCP8.5, with 60 stations experiencing less than half of wet days as snow days (Figure 2e) and a maximum decline of $-13.8 \%$ (Figure 2g). However, declines in snowfall frequency decelerate at over $98.7 \%$ of stations (Figure $2 \mathrm{~h}$ ), with only 85 stations experiencing less than $50 \%$ snowfall frequency on average (Figure $2 \mathrm{f}$ ), highlighting the impact of mitigation. 
RCP8.5
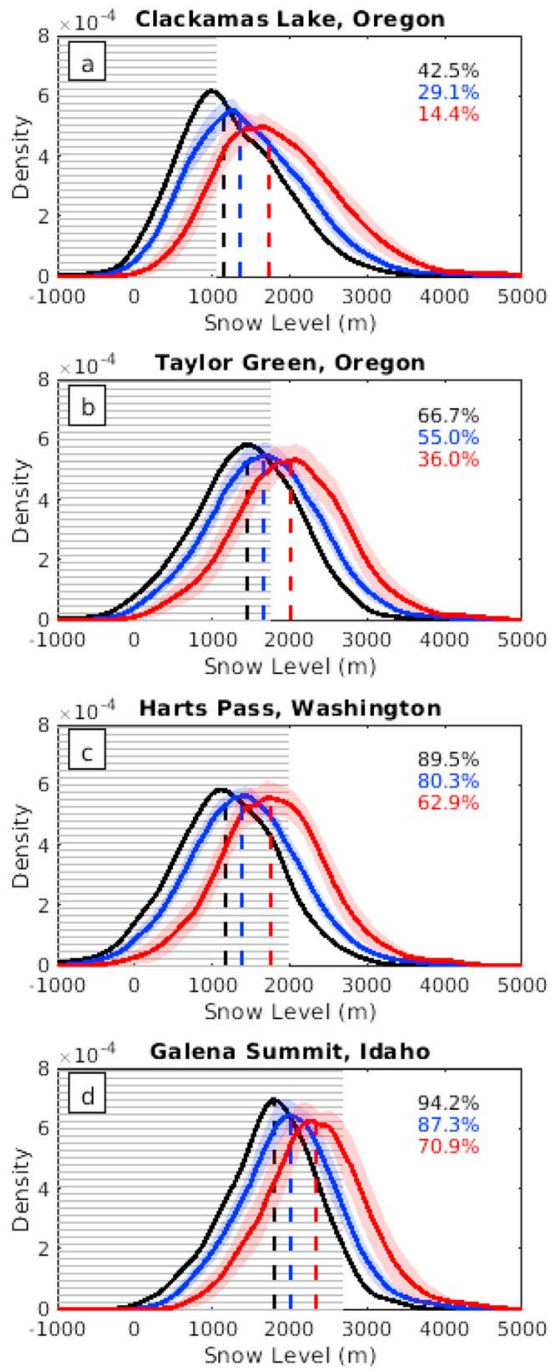

RCP4.5
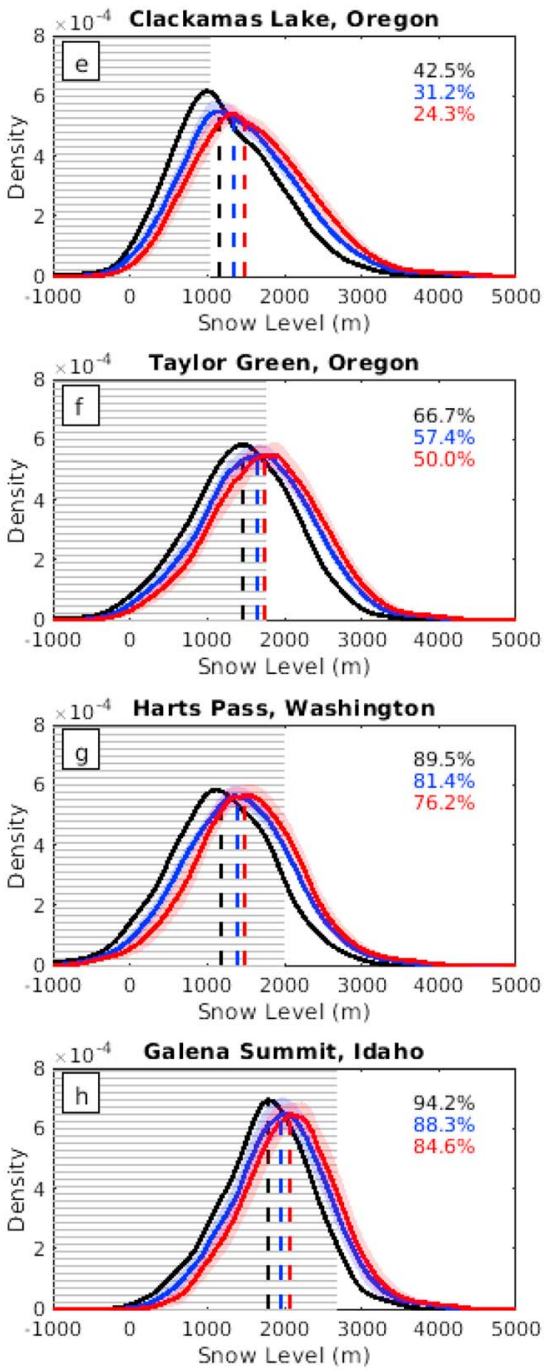

Figure 3. (left) RCP8.5 and (right) RCP4.5 distributions of snow levels at (a and e) Clackamas Lake, (b and f) Taylor Green, (c and g) Harts Pass, and (d and h) Galena Summit SNOTEL stations. ERA5 historical distributions (1981-2005) are in black, and median CMIP5 distribution shifts at midcentury (2028-2052) and end-of-century (2075-2099) periods are in blue and red, respectively. One standard deviation across CMIP5 models is shaded, and dashed lines are median heights. Gray stippling indicates heights below station elevation. Percentages are snowfall frequencies over each period (from Figures $1 \mathrm{~b}, 2 \mathrm{a}, 2 \mathrm{~b}, 2 \mathrm{e}$, and $2 \mathrm{f}$ ). The $y$ axis refers to the probability density of the distribution, derived from kernel density estimation using 1-m bin width.

To illustrate how warming affects snowfall frequency at individual stations, four examples of projected SL distributions are provided, covering a range of elevations and geographies across the NUS (Figure S5): windward side of the Cascades (Clackamas Lake, Oregon), leeward side of the Cascades (Harts Pass, Washington), Wallowa Mountains (Taylor Green, Oregon), and Boulder Mountains (Galena Summit, Idaho). Results reveal a robust shift in all SL distributions by midcentury, as the rise in SLs at percentiles 1-99 is positive within 1 standard deviation across the multimodel ensemble (Figures 3a-3h). Median SLs rise nonlinearly, which can lead to a nonlinear decline in snowfall frequency, but the rate of decline is affected by disproportionate changes across the distribution. For example, Harts Pass experiences a more pronounced shift in the low-altitude tail of the distribution between midcentury and end-of-century periods (Figure 3c), so snowfall frequency declines at a higher rate than during the first half of the century ( $-9.2 \%$ versus $-17.4 \%)$. Conversely, Clackamas Lake exhibits the greatest increase in the rate at which the median SL rises, but declines in snowfall frequency are virtually identical between periods owing to low-altitude-tail behavior (Figure 3a). Overall, the increase in median RCP8.5 SL ranges from $+547 \mathrm{~m}$ at 
RCP8.5
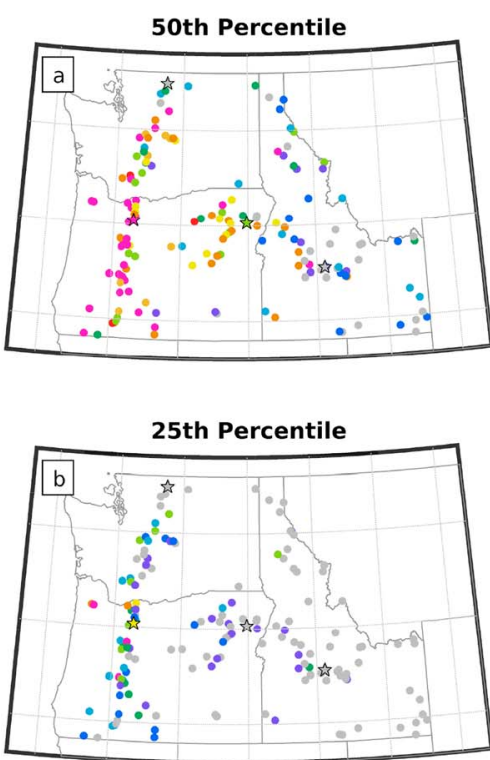

10th Percentile

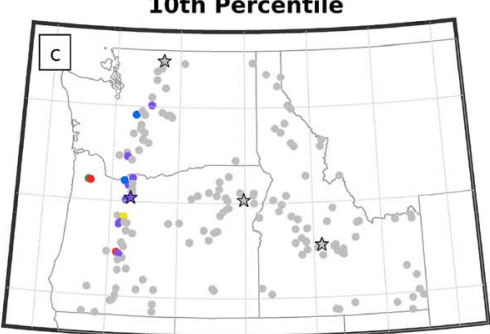

RCP4.5

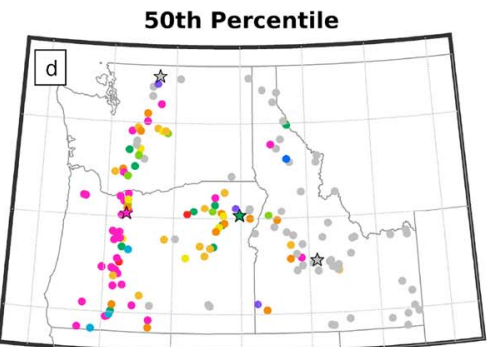

25th Percentile

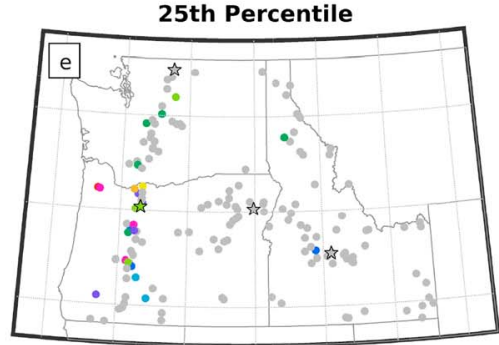

10th Percentile

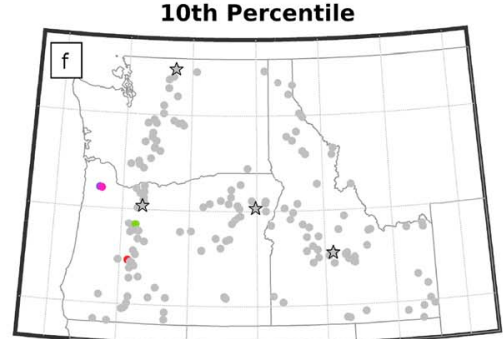

$\geq 2091$

2081

2071

2061

2051

2041

2031

2021

2011

2008

$\leq 2007$

Figure 4. (left) RCP8.5 and (right) RCP4.5 critical snowfall frequency years based on the (a and d) 50th, (b and e) 25th, and ( $\mathrm{c}$ and $\mathrm{f}$ ) 10th percentile thresholds, represented as the median across models. Magenta circles indicate snow level percentiles above station elevation prior to the first year of RCP simulations $(\leq 2007)$, whereas gray circles indicate percentiles still below station elevation by the end of the simulation $(\geq 2091)$. Stars indicate select stations analyzed in Figure 3.

Galena Summit (Figure 3d) to $+593 \mathrm{~m}$ at Clackamas Lake (Figure 3a), and the decline in snowfall frequency ranges from $-23.3 \%$ at Galena Summit (Figure 3d) to $-30.7 \%$ at Taylor Green (Figure 3b). Under RCP4.5, there is a lower rise in SLs by 2100 (median $<341 \mathrm{~m}$ ), and thus a smaller decline in snowfall frequency (<19\%; Figures 3e-3h).

Figure 4 displays critical years, which represent the first year of the first 10-year period when average snow days at a station are less than half (Figures $4 \mathrm{a}$ and $4 \mathrm{~d}$ ), one quarter (Figures $4 \mathrm{~b}$ and $4 \mathrm{e}$ ), and one tenth (Figures $4 \mathrm{c}$ and $4 \mathrm{f}$ ) of wet days. By the last decade of the twenty-first century, $84.1 \%$ of stations across the region are projected to experience no more than half of wet days as snow days (i.e., snowfall frequency $\leq 50 \%$; Figure $4 \mathrm{a}$ ) under RCP8.5, compared with $14.7 \%$ of stations in the current climate (Figure 1b). In addition, $43.3 \%$ and $9.6 \%$ of stations will experience decadal-average snowfall frequencies below $25 \%$ and $10 \%$, respectively (Figures $4 \mathrm{~b}$ and $4 \mathrm{c}$ ). Under RCP4.5, critical years are projected to occur an average of six, five, and one year(s) later at the 50th, 25th, and 10th percentiles, respectively (Figures 4d-4f), although delays are nonlinear over the twenty-first century. For stations with RCP8.5 critical years occurring by 2050 at the 50 th percentile, the average delay under RCP4.5 is two years, whereas the average delay for stations with RCP8.5 critical years after 2050 is 12 years, indicating the divergence between pathways following midcentury.

Regional variability in critical year estimates is considerable. All Idaho stations continue to experience at least 10\% snowfall frequency beyond the end of the century ( $\geq 2091$; Figures $4 \mathrm{c}$ and $4 \mathrm{f}$ ). Conversely, snowfall frequency is already below $50 \%$ at many stations in the Cascades ( $\leq 2007$; Figures $4 \mathrm{a}$ and $4 \mathrm{~d})$. In a broader 
sense, results suggest that by the end of the twenty-first century, over 90\% of SNOTEL stations across the NUS will continue to receive snow, but many of these locations will experience more than half of wet days as rain. Indeed, the majority of stations experiencing $>50 \%$ snowfall frequency historically (Figure 1b) will experience $\leq 50 \%$ snowfall frequency by just 2070 (Figures $4 \mathrm{a}$ and $4 \mathrm{~d}$ ).

Under RCP8.5, standard error due to model variability is at most four years (not shown), suggesting that the $20 \mathrm{GCMs}$ chosen represent a sufficient sample size to estimate critical years based on a decadal mean. Nevertheless, there is notable model uncertainty in estimates at many SNOTEL stations. Across the CMIP5 ensemble, the median absolute deviation of critical years is above 10 years at $28.7 \%, 21.7 \%$, and $1.9 \%$ of stations for 50th, 25th, and 10th percentile thresholds, respectively (Figure S6). Critical years are also sensitive to lapse rate chosen for SL extrapolation, with departures varying 0-22 years depending on location (Figure S7 and Tables S5-S13). Thus, there is a degree of uncertainty in individual estimates, but spatial patterns indicate areas of the NUS that will likely experience critical declines in snowfall frequency over this century. Critical years, therefore, should be interpreted as relative estimates and not precise predictions of the year in which snowfall frequency will cross the specified threshold.

\section{Conclusions and Discussion}

Warming temperatures will lead to a reduction in snowpack and snowfall throughout the NUS (Feng \& $\mathrm{Hu}$, 2007; Mote et al., 2018; Stewart et al., 2005), increasing the vulnerability of snow-dependent watersheds. Using an atmospheric approach to assess the spatiotemporal variability in projected snowfall frequency at individual SNOTEL stations across the NUS, results indicate that frequency declines over the twenty-first century at all stations under both business-as-usual and moderate emissions pathways, as expected from warming temperatures. However, at virtually all stations, business-as-usual emissions lead to an increased rate of decline throughout the second half of the century, whereas mitigating emissions results in decreased rates. Estimates of years when stations will experience critical snowfall frequency declines indicate regions of concern by midcentury (e.g., Cascades), and regions that may not experience critical declines this century (e.g., Boulders), although near-term mitigation may delay or prevent the occurrence of critical years. Nevertheless, neighboring stations may experience critical years over 50 years apart within these broad regions, demonstrating the necessity for the pointwise assessment outlined here.

Critical years establish time horizons for severe declines in average snowfall frequency, but there are caveats that should be considered when interpreting results. Estimates rely on assumptions made during extrapolation of SLs below surface including seasonally and spatially uniform SL displacement and wet-day lapse rates across the NUS. However, displacement (White et al., 2010; Minder et al., 2011; Schauwecker et al., 2017) and lapse rate (Blandford et al., 2008; Dobrowski et al., 2009; Pepin \& Losleben, 2002) vary depending on geographic location and meteorological conditions, and many station-specific critical years demonstrate high sensitivity to lapse rate choice. The median absolute deviation on estimates also reveals substantial model variability at many locations. Further work reducing uncertainty in estimates would improve the utility of our approach, which is highly extensible to other geographies as this methodology can be applied to coarse-resolution models over uneven terrain to estimate local changes in snowfall frequency in present and future climate.

By analyzing the temperature-driven decline in snowfall frequency at individual stations, results can better inform water resource management and resilience planning. The nonlinearity in snowfall frequency declines over the twenty-first century suggests that associated impacts will accelerate in future decades without implementation of mitigation strategies, which has implications for short-term versus long-term planning. This is particularly important in lower elevation locations, which are more sensitive to changes in temperature (Mote et al., 2018) and, thus, more susceptible to snow droughts (Dierauer et al., 2019). Yet even in a stationary climate, the interplay between snowpack and its surrounding environment (e.g., wildfire, canopy density, and slope angle) is integral to water storage. Therefore, a thorough understanding of how snow cover and water availability may change throughout the twenty-first century requires consideration of the local climatology, meteorology, and surrounding environment. 


\section{Acknowledgments}

The authors thank Andy Martin and anonymous reviewers for the useful comments that improved this paper. We acknowledge the World Climate Research Programme's Working Group on Coupled Modelling, which is responsible for CMIP, and we thank the climate modeling groups (listed in Table S4) for producing and making available their model output. We acknowledge ERA5 (https://climate. copernicus.eu/climate-reanalysis) and SNOTEL (https://wcc.sc.egov.usda gov/reportGenerator/) for publicly available data sets. Research is supported by Clackamas River Water Providers, Water Environment Services, the Portland State University Institute for Sustainable Solutions, and the Portland State University College of Liberal Arts and Sciences (A.J.C.), as well as U.S. National Science Foundation AGS-1621554 (P.C.L.)

\section{References}

Abatzoglou, J. T. (2011). Influence of the PNA on declining mountain snowpack in the western United States. International Journal of Climatology, 31(8), 1135-1142. https://doi.org/10.1002/joc.2137

Ashfaq, M., Ghosh, S., Kao, S.-C., Bowling, L. C., Mote, P., Touma, D., et al. (2013). Near-term acceleration of hydroclimatic change in the western U.S. Journal of Geophysical Research: Atmospheres, 118, 10,676-10,693. https://doi.org/10.1002/jgrd.50816

Blandford, T. R., Humes, K. S., Harshburger, B. J., Moore, B. C., Walden, V. P., \& Ye, H. (2008). Seasonal and synoptic variations in nearsurface air temperature lapse rates in a mountainous basin. Journal of Applied Meteorology and Climatology, 47(1), 249-261. https://doi. org/10.1175/2007JAMC1565.1

Bradley, R. S., Keimig, F. T., Diaz, H. F., \& Hardy, D. R. (2009). Recent changes in freezing level heights in the tropics with implications for the deglacierization of high mountain regions. Geophysical Research Letters, 36, L17701. https://doi.org/10.1029/ 2009GL037712

Caldwell, P. (2010). California wintertime precipitation bias in regional and global climate models. Journal of Applied Meteorology and Climatology, 49(10), 2147-2158. https://doi.org/10.1175/2010JAMC2388.1

Copernicus Climate Change Service (C3S) (2017). ERA5: Fifth generation of ECMWF atmospheric reanalyses of the global climate. Copernicus Climate Change Service Climate Data Store (CDS), 22 February 2019. https://cds.climate.copernicus.eu/cdsapp\#!/ home

Danco, J. F., DeAngelis, A. M., Raney, B. K., \& Broccoli, A. J. (2016). Effects of a warming climate on daily snowfall events in the Northern Hemisphere. Journal of Climate, 29(17), 6295-6318. https://doi.org/10.1175/JCLI-D-15-0687.1

Dierauer, J. R., Allen, D. M., \& Whitfield, P. H. (2019). Snow drought risk and susceptibility in the western United States and southwestern Canada. Water Resources Research, 55, 3076-3091. https://doi.org/10.1029/2018WR023229

Dobrowski, S. Z., Abatzoglou, J. T., Greenberg, J., \& Schladow, S. G. (2009). How much influence does landscape-scale physiography have on air temperature in a mountain environment? Agricultural and Forest Meteorology, 149(10), 1751-1758. https://doi.org/10.1016/j. agrformet.2009.06.006

Feng, S., \& Hu, Q. (2007). Changes in winter snowfall/precipitation ratio in the contiguous United States. Journal of Geophysical Research, 112, D15109. https://doi.org/10.1029/2007JD008397

Hamlet, A. F., Mote, P. W., Clark, M. P., \& Lettenmaier, D. P. (2005). Effects of temperature and precipitation variability on snowpack trends in the western United States. J. Climate, 18(21), 4545-4561. https://doi.org/10.1175/JCLI3538.1

Jennings, K. S., Winchell, T. S., Livneh, B., \& Molotch, N. P. (2018). Spatial variation of the rain-snow temperature threshold across the Northern Hemisphere. Nature Communications, 9(1), 1148. https://doi.org/10.1038/s41467-018-03629-7

Kapnick, S., \& Hall, A. (2012). Causes of recent changes in western North American snowpack. Climate Dynamics, 38(9-10), 1885-1899. https://doi.org/10.1007/s00382-011-1089-y

Kapnick, S. B., \& Delworth, T. L. (2013). Controls of global snow under a changed climate. Journal of Climate, 26(15), 5537-5562. https:// doi.org/10.1175/JCLI-D-12-00528.1

Klos, P. E., Link, T. E., \& Abatzoglou, J. T. (2014). Extent of the rain-snow transition zone in the western U.S. under historic and projected climate. Geophysical Research Letters, 41, 4560-4568. https://doi.org/10.1002/2014GL060500

Knowles, N., Dettinger, M. D., \& Cayan, D. R. (2006). Trends in snowfall versus rainfall in the western United States. Journal of Climate, 19(18), 4545-4559. https://doi.org/10.1175/JCLI3850.1

Knox, J. A., Nevius, D. S., \& Knox, P. N. (2017). Two Simple and Accurate Approximations for Wet-Bulb Temperature in Moist Conditions, with Forecasting Applications. Bulletin of the American Meteorological Society, 98, 1897-1906. https://doi.org/10.1175/BAMS-D-160246.1

Liu, Z., Mehran, A., Phillips, T. J., \& AghaKouchak, A. (2014). Seasonal and regional biases in CMIP5 precipitation simulations. Climate Research, 60(1), 35-50. https://doi.org/10.3354/cr01221

Lundquist, J., Neiman, P., Martner, B., White, A., Gottas, D., \& Ralph, F. (2008). Rain versus snow in the Sierra Nevada, California: Comparing Doppler profiling radar and surface observations of melting level. Journal of Hydrometeorology, 9(2), 194-211. https://doi. org/10.1175/2007JHM853.1

Lute, A. C., Abatzoglou, J. T., \& Hegewisch, K. C. (2015). Projected changes in snowfall extremes and interannual variability of snowfall in the western United States. Water Resources Research, 51, 960-972. https://doi.org/10.1002/2014WR016267

Maurer, E. P., Wood, A. W., Adam, J. C., Lettenmaier, D. P., \& Nijssen, B. (2002). A long-term hydrologically based dataset of land surface fluxes and states for the conterminous United States. Journal of Climate, 15(22), 3237-3251. https://doi.org/10.1175/15200442(2002)015<3237:ALTHBD>2.0.CO;2

Mesinger, F., DiMego, G., Kalnay, E., Mitchell, K., Shafran, P. C., Ebisuzaki, W., et al. (2006). North American Regional Reanalysis. Bulletin of the American Meteorological Society, 87(3), 343-360. https://doi.org/10.1175/BAMS-87-3-343

Minder, J. R., Durran, D. R., \& Roe, G. H. (2011). Mesoscale controls on the mountainside snow line. Journal of the Atmospheric Sciences, 68(9), 2107-2127. https://doi.org/10.1175/JAS-D-10-05006.1

Minder, J. R., Mote, P. W., \& Lundquist, J. D. (2010). Surface temperature lapse rates over complex terrain: Lessons from the Cascade Mountains. Journal of Geophysical Research, 115, D14122. https://doi.org/10.1029/2009JD013493

Mote, P. W., Hamlet, A. F., Clark, M. P., \& Lettenmaier, D. P. (2005). Declining mountain snowpack in western North America. Bulletin of the American Meteorological Society, 86(1), 39-50. https://doi.org/10.1175/BAMS-86-1-39

Mote, P. W., Li, S., Lettenmaier, D. P., Xiao, M., \& Engel, R. (2018). Dramatic declines in snowpack in the western US. npj Climate and Atmospheric Science, 1(1). https://doi.org/10.1038/s41612-018-0012-1

Nolin, A. W., \& Daly, C. (2006). Mapping “at risk” snow in the Pacific Northwest. Journal of Hydrometeors, 7(5), 1164-1171. https://doi.org/ 10.1175/JHM543.1

Pepin, N., \& Losleben, M. (2002). Climate change in the Colorado Rocky Mountains: Free air versus surface temperature trends. Int. J. Climatol., 22(3), 311-329. https://doi.org/10.1002/joc.740

Rupp, D. E., Abatzoglou, J. T., Hegewisch, K. C., \& Mote, P. W. (2013). Evaluation of CMIP5 20th century climate simulations for the Pacific Northwest USA. Journal of Geophysical Research: Atmospheres, 118, 10,884-10,906. https://doi.org/10.1002/jgrd.50843

Schauwecker, S., Rohrer, M., Huggel, C., Endries, J., Montoya, N., Neukom, R., et al. (2017). The freezing level in the tropical Andes, Peru: An indicator for present and future glacier extents. Journal of Geophysical Research: Atmospheres, 122, 5172-5189. https://doi.org/ 10.1002/2016JD025943

Schmith, T. (2008). Stationarity of regression relationships: Application to empirical downscaling. Journal of Climate, 21(17), 4529-4537. https://doi.org/10.1175/2008JCLI1910.1 
Serreze, M. C., Clark, M. P., Armstrong, R. L., McGinnis, D. A., \& Pulwarty, R. S. (1999). Characteristics of the western United States snowpack from snowpack telemetry (SNOTEL) data. Water Resources Research, 35(7), 2145-2160. https://doi.org/10.1029/ 1999WR900090

Smith, C. D., Kontu, A., Laffin, R., \& Pomeroy, J. W. (2017). An assessment of two automated snow water equivalent instruments during the WMO Solid Precipitation Intercomparison Experiment. The Cryosphere, 11(1), 101-116. https://doi.org/10.5194/tc-11-101-2017

Stewart, I. T., Cayan, D. R., \& Dettinger, M. D. (2005). Changes toward earlier streamflow timing across western North America. Journal of Climate, 18(8), 1136-1155. https://doi.org/10.1175/JCLI3321.1

Taylor, K. E., Stouffer, R. J., \& Meehl, G. A. (2012). An overview of CMIP5 and the experiment design. Bulletin of the American Meteorological Society, 93(4), 485-498. https://doi.org/10.1175/BAMS-D-11-00094.1

Thomson, A. M., Calvin, K. V., Smith, S. J., Kyle, G. P., Volke, A., Patel, P., et al. (2011). RCP4.5: A pathway for stabilization of radiative forcing by 2100. Climatic Change, 109(1-2), 77-94. https://doi.org/10.1007/s10584-011-0151-4

USGCRP (2017). In D. J. Wuebbles, D. W. Fahey, K. A. Hibbard, D. J. Dokken, B. C. Stewart, \& T. K. Maycock (Eds.), Climate Science Special Report: Fourth National Climate Assessment (Vol. 1, p. 470). Washington, DC, USA: U.S. Global Change Research Program. https://doi.org/10.7930/J0J964J6

Wang, S., Zhang, M., Pepin, N. C., Li, Z., Sun, M., Huang, X., \& Wang, Q. (2014). Recent changes in freezing level heights in High Asia and their impact on glacier changes. Journal of Geophysical Research: Atmospheres, 119, 1753-1765. https://doi.org/10.1002/2013JD020490

White, A. B., Gottas, D. J., Henkel, A. F., Neiman, P. J., Ralph, F. M., \& Gutman, S. I. (2010). Developing a Performance Measure for SnowLevel Forecasts. Journal of Hydrometeorology, 11, 739-753. https://doi.org/10.1175/2009JHM1181.1

Zhang, Y., \& Guo, Y. (2011). Variability of atmospheric freezing-level height and its impact on the cryosphere in China. Annals of Glaciology, 52(58), 81-88. https://doi.org/10.3189/172756411797252095 